\title{
Urban Risk Assessment of Lahar Flows in Merapi Volcano (Study Case: Muntilan Urban Area, Central Java)
}

\author{
Cosmas Bambang Sukatja, Sudibyakto, RPGA Voskuil
}

Received: 22122013 / Accepted:18 03 2014/ Published online: 30062014

(c) 2014 Faculty of Geography UGM and The Indonesian Geographers Association

\begin{abstract}
The objective of the research was to analyse probability of lahar flows occurrence in Muntilan urban area, Central Java. By using integrated methods, which involve the numerical simulation program, Geographic Information System (GIS), Remote Sensing (RS) and field verification to produce lahar flows Hazard Map and Risk Map. Muntilan urban area located at western flank of Merapi volcano, and in down stream of Lamat river. The river is Lahar River that is endangering from Merapi volcano, which flowing down to cuts a cross of that area. Therefore, Muntilan urban area is vulnerable area from lahar flows disaster. Lahar flows, generally occur during intense rainfall on saturated volcanic deposit in upper stream of river or wall of volcano. Lahar flows are extremely dangerous especially to those living in valley areas near a volcano, which can undercut banks and cause houses destruction situated on the banks, and can bury and destroy resident, structures, infrastructure facilities including roads and bridges. Meanwhile, development of Muntilan urban area that caused many illegal settlements appears surrounding that area. Occasionally, un-benefit people constructing house in disaster prone area, such as down stream of river side that have lahar flows risk. The research was concluded that lahar flow occurrence in 100 years return period will be buried the Muntilan urban area. With the methods integrating of GIS, RS, field verification can be done analysing of lahar flows hazard map, and risks map to produce risk assessment in Muntilan urban area.
\end{abstract}

Keywords: lahar flows, urban area, risk assessment.

Abstrak Tujuan dari penelitian ini adalah untuk menganalisis kemungkinan terjadinya aliran lahar di perkotaan Muntilan , Jawa Tengah. Metode penelitian ini merupakan metode terpadu dengan melibatkan program simulasi numerik, Sistem Informasi Geografis (SIG), Penginderaan Jauh (PJ) dan verifikasi lapangan untuk menghasilkan Peta Bahaya dan Peta Risiko aliran lahar. Daerah perkotaan Muntilan terletak di sisi barat Gunung Merapi hingga bagian hilir sungai Lamat. Sungai tersebut adalah sungai dengan ancaman banjir lahar dari Gunung Merapi, yang mengalir ke persilangan dari daerah tersebut. Oleh karena itu, daerah perkotaan Muntilan adalah daerah rentan dari bencana banjir lahar. Aliran lahar umumnya terjadi saat curah hujan yang intens pada endapan vulkanik jenuh di hulu sungai atau sisi gunungapi. Aliran lahar sangat berbahaya terutama bagi mereka yang tinggal di daerah lembah dekat gunungapi, yang dapat menghancurkan rumah sepanjang sisi sungai dan dapat mengubur penduduk, struktur bangunan, dan fasilitas infrastruktur termasuk jalan dan jembatan. Sementara itu, pengembangan daerah perkotaan Muntilan menyebabkan banyak pemukiman ilegal muncul di sekitar daerah tersebut. Terkadang, penduduk membangun rumah di daerah rawan bencana, seperti sisi hilir sungai yang memiliki risiko tinggi terhadap banjir lahar. Penelitian ini menyimpulkan bahwa terjadinya aliran lahar dalam kala ulang 100 tahun akan mengubur sebagian daerah perkotaan Muntilan. Dengan metode mengintegrasikan SIG, PJ, dan verifikasi lapangan analisis dari peta bahaya dan peta risiko banjir lahar dapat dilakukan untuk menghasilkan penilaian risiko di daerah perkotaan Muntilan.

Kata kunci: Sistem evaluasi lahan otomatis, survey tanah, kualitas lahan, karakteristik lahan, interpretasi citra.

\section{Introduction}

Lahar is an Indonesian word describing mudflows and debris flows that originate from the slopes of a volcano [Lavigne, 2000]. Both types of flows contain a high concentration of rock debris to give them the internal strength necessary to transport high boulders as well as buildings and bridges and to exert extremely high impact forces against objects in their paths. The size of lahars materials is variety, from several centimeters

\section{C.B. Sukatja}

Balai Sabo Yogyakarta

Email: sukatja@sabo.go.id

Sudibyakto

Faculty of Geography Universitas Gadjah Mada, Yogyakarta

RPGA Voskuil

Faculty of Geo-information Science and Earth Observation,

University of Twente, the Netherlands of diameters, flowing less than one meter per second. On the steep slope, particularly unvegetated slopes are often good sites to observe such small flows during a heavy rain. At the other extreme, they can be a few hundred meters wide, tens of meters deep, flow at several tens of meters per second, and travel over 100 kilometers from a volcano [Power, 1985, Yamasita, 2006].

Muntilan urban area is one of district in Magelang regency, which located in the lahar flows disaster prone area of Merapi volcano. Related to a new Indonesian government's policy declaring the Local Government has autonomy in economical matters, the Muntilan district will imply to explore the local natural resources to improve a local economic income.

Considering ever increasing population growth in Muntilan urban area, the expansions of the settlements, 
many people in and around the area are now forced to build their houses in prone lahars flow areas. Most often, the construction of buildings is taking place with very little or without any regard to lahars flow. The last lahars flow occurs in that area in 1932, so many inhabitants was not familiar with the lahars flow disaster, especially their new generation and new residents. Also, according to the interval eruption and direction of pyroclastic flows is not indubitable, therefore the settlements and socio-economic activities around the western slope of the volcano, have became potentially endangered. Hence, countermeasures to prevent or mitigate the negative effects resulting from lahar flows should be taken.

In order to minimize the impacts and at to optimize land utilization in around Muntilan urban area, the better planning and mitigation measures against lahars flows are absolutely required. This requires a comprehensive risk assessment in the area.

The results of the research should highlight the present condition of lahars flow prone areas and it's surrounding. These results should at least be able to predict the future conditions of such places. In this way, sustainable development of the area would be improved. On this basic, a framework for risk assessment due to the lahars flow problems may be worked out.

One of the most important tools for the design and formulation of policies and strategies for the reduction of the risk of the population is the production of Zone Risk maps that can be used by the urban development planers and local authorities.

Risk assessment of lahars flow impact should be part of the activities to diminish the impacts of lahars flow occurrence. The aim of this study is to present the way in which computer tools, such as a Geographic Information System (GIS), combined with remote sensing technique, contributes to the analysis and representation of the information required for risk assessment of lahar flows.[Barrough, 1989, Van westen, et.al, 2005]

The implementation and effort for supporting the research objective must be known cause of lahar flows occurrence. The lahar flows will happen with presence of three natural elements, as volcanic deposits, slope of channel and rainfall intensity which triggering the lahar flows occurrence. The location of volcanic deposit will decide of direction of lahar flows occurrence. When the area threatened of lahar flow disaster can be predicted and the elements at risk area is knowing, then risk assessment can be calculated. A GIS can contribute to solve the data integration problems through their wide capabilities to input analyses and manage the multi-sources data involved in the risk assessment of lahar flows impact processes. The adoption of both techniques, to estimate risk assessment of lahar flows impact, provides a new powerful approach to analyses and represents it, even when the amount of data available for evaluation is scarce. The introduction of a set of computer tools in risk assessment of lahar flows impact processes have set the need to adapt risk assessment of lahar flows impact methodologies to a new operating environment. This will be achieved by designing a computational method, where the parameters and procedures required to estimate potential volcanic risk are clearly identified for each of volcanic phenomena.

The main objective of the research work is to produce risk map of lahar flows in Muntilan urban area using integrated methods, which involve the use of Remote Sensing, Geographical Information Systems and field verification.

The specific objectives of the research are the following: (1) identify the distribution of pyroclastic deposits in surrounding of Merapi slopes area, especially in Muntilan urban area (based on temporal remote sensing data, volcanology Survey Indonesia), (2) identify distribution of lahar flows deposits material in alongside of Lamat river, based on JICA reports 1980 . Report of Review Master Plan of Mt. Merapi, 2001 and field interviews, (3) analyze the morphology of channel data to get the probability of lahars over flow in the study area, (4) construct the lahar flows hazard map, and (5) use amount of elements risk in Muntilan urban area to assess of lahar flows risk in study area, such as people, sources, properly, environment, livelihood.

\section{Research Methodology}

This research was conducted in Muntilan urban area, Central Java. Due to the nature of this research, the methodology adopted for the entire work was systematically divided into 4 (four) phases. The data collected during these phases was used to prepare the final hazard and risk maps. The four phases were as follows: (1) data Preparation: Study literature, collecting secondary data, (2) pre-field work: GIS Work using digital orthophoto to get of DEM, slope, aspect maps, (3) field work: Data collection about volcano eruption, pyroclastic flows relevant data, channel capcity and Interview people about lahar flows events, and (4) post-field work.

For estimation the vulnerability of lahar flows with JSAS Numerical Simulation software. And using the result of that simulation and integrated methods to create the Hazard and Risk of lahar flows Map, with Arc view software. Identification and inventory of elements at risk conduct by digitizing the land use type directly from aerial photograph. The quantitative estimation of risk may be determined by using the following formula [ITC Hodule, 2004]:

\section{$\mathrm{R}($ Risk $)=\mathrm{H}($ harsad $) \mathrm{x}$ V(Vulnerability) $\mathrm{x}$ A(Amount)}

Risk analysis can be described as follow:

1. Lahar flows Hazard $(\mathrm{H})$ is probability (potential hazard) of the event with a certain magnitude.

2. The vulnerability of the elements at risk (V) (building stock, life lines, critical facilities, population, economic activities) exposed to the event with a certain magnitude

3. The amount of costs (A) of the elements at risk 


\section{Result and Discusion}

Vulnerability of Lahar flows in Muntilan urban area can be estimated with JSAS Numerical Simulation soft ware. In order to processing the input data to the soft ware, must be done the un-generate works by using ArcInfo software. Un-generate works to converts contour vector data of digital ortho photo to the grid data (X,Y and $\mathrm{Z}$ ). Besides the grid data necessary to input several parameters such as inflow point \& hydrograph of lahar flows.

At last, by using JSAS Simulation software would be present of lahar flows distribution and depth in Muntilan urban area, as presented on Figure 1.

A simulation of the hazard lahar flows as the most hazardous event at Merapi volcano has been constructed by the numerical simulation. Considering a deviating propagation of flowing mechanism of lahar flows in the Muntilan urban area, this map was created with lahar flows hazard scenarios mechanism for 100 year return period.

According the result of JSAS Numerical Simulation the sediments of lahar flows will covered in down stream of Lamat River. The sediments buried in that area on elevation $487 \mathrm{~m}$ (Ngrajeg sub-village, Ngadipuro village, $+485 \mathrm{~m}$ ) until $312 \mathrm{~m}$ (Gunung Pring village, $+313 \mathrm{~m}$ ). The dimension of sediment deposit around $15 \mathrm{~km} 2$, with length : $5.8 \mathrm{~km}$ and wide : $2.59 \mathrm{~km}$.

The elements at risk data provide information required to characterise the value of population, properties, economic activities, including public services in the given area. The data layer, which is implemented to calculate an impact level in Muntilan urban area is buried by lahar flows, it is focused on population, infrastructures (settlements, schools, health centres, bridge and road network and natural land (irrigated and nonirrigated agriculture, commercial plantation, forest, and bareland). This field area is administratively covered within Muntilan, Gunung Pring and Villages in Muntilan District and Ketunggeng, Ngadipuro, Banyubiru Villages in Dukun District, Magelang Regency, Central Java Province.

In connection with the focus of this paper, it is limited only risk assessment in Muntilan urban area, then the next calculation of lahar flows impact in element at risk area is only administratively covered within Muntilan District, such as Muntilan and Gunung Pring villages.

Lahar hazard area is threatened area from the lahar flows occurrence, usually that area be related in a certain way buried with lahar material. Lahar Hazard map in the Muntilan urban area presented in 3 classifications be based on depth of lahar flows material which buried at field area, see Table 1.

The phenomena of lahar flows affected in the down stream and three dimensions modeling of lahar distribution in down stream of Lamat river can be presented in Figure 2.

Hazard map of lahar flows in Muntilan urban area presented in Figure 3, is constitute of threatened area from the lahar flows occurrence. According the result of JSAS Numerical Simulation, the distribution of lahar flows materials in Muntilan urban area is not same of depth. Diversification of lahars material are depends of contour and condition of river channel.

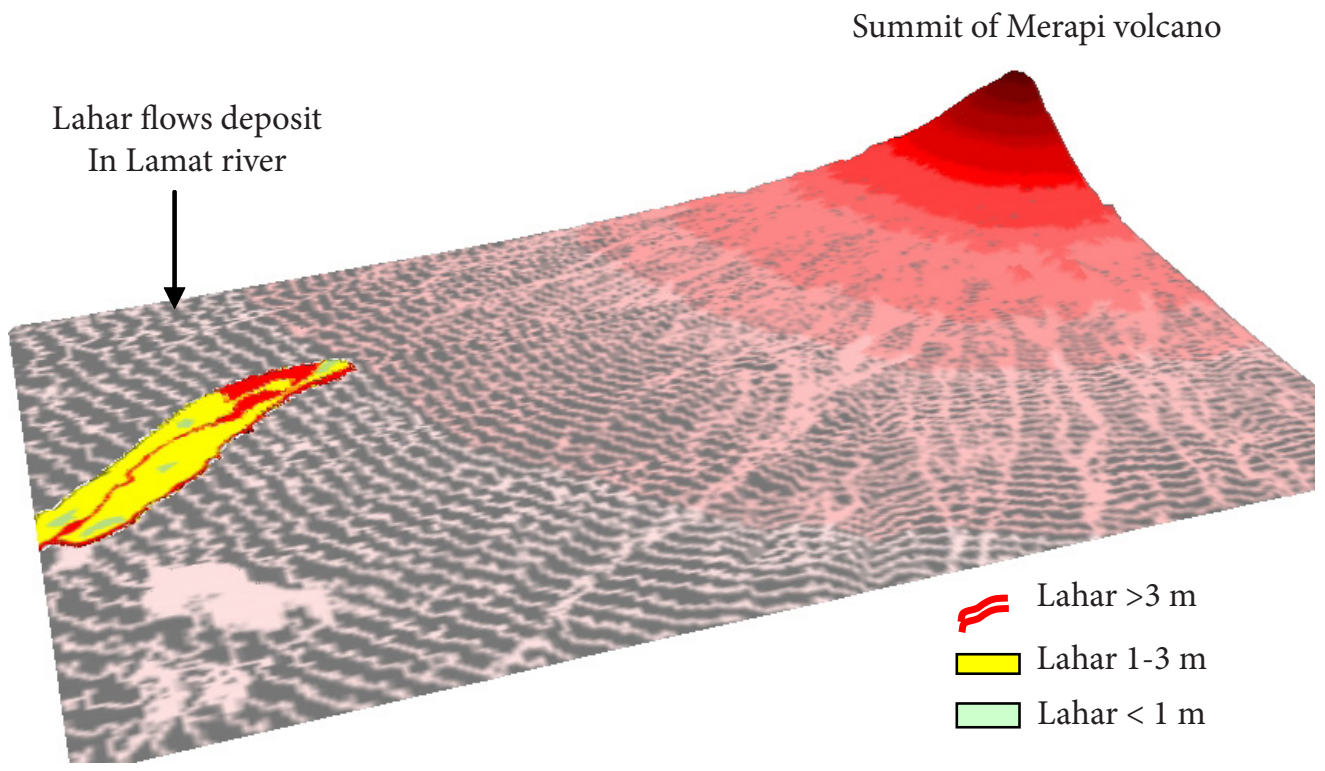

Figure 1. The JSAS simulation result of distribution and depth lahar flows. (Itoh, 2000) 


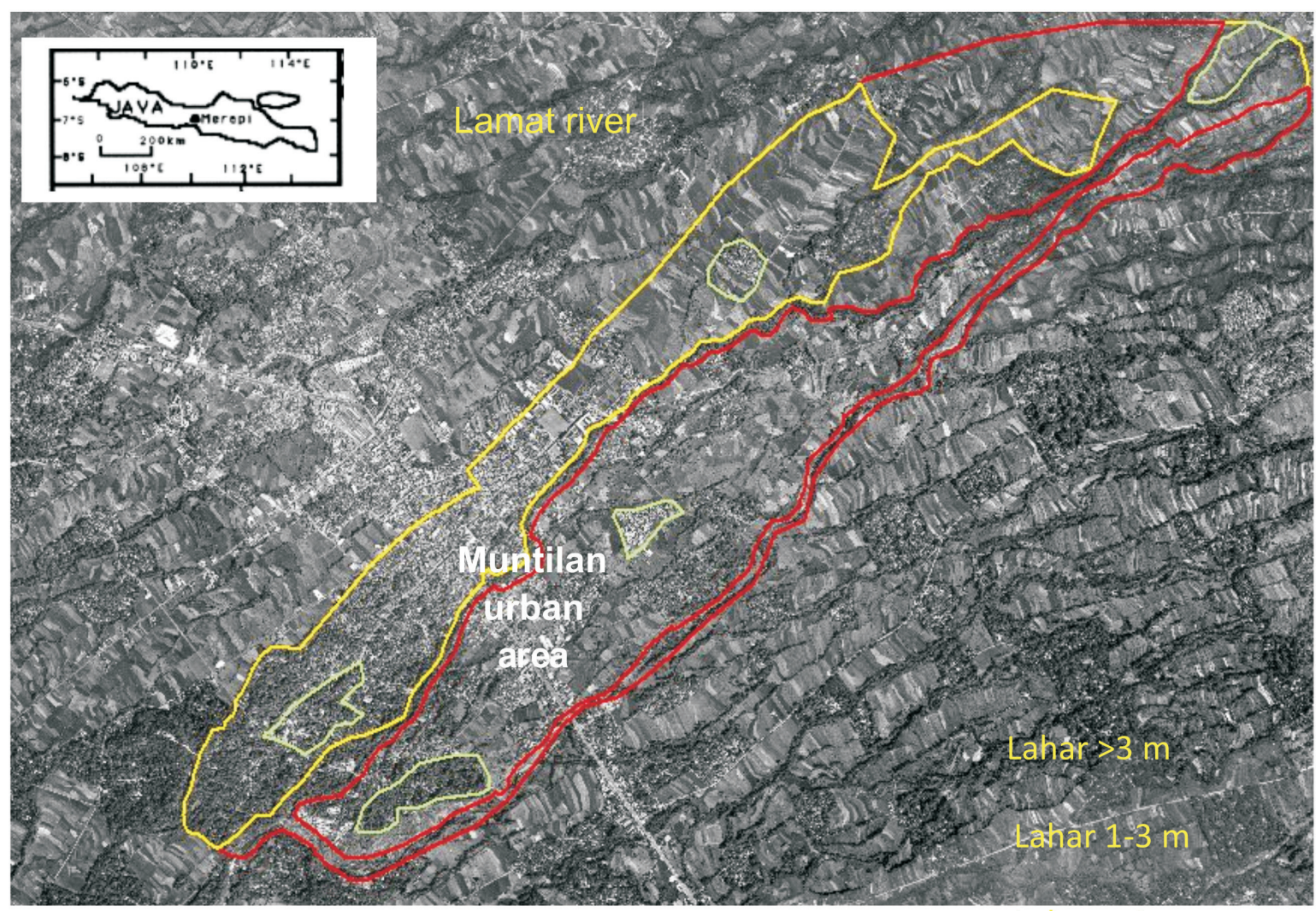

Figure 2. Phenomena area affected of Lahar flows in down Stream of Lamat River

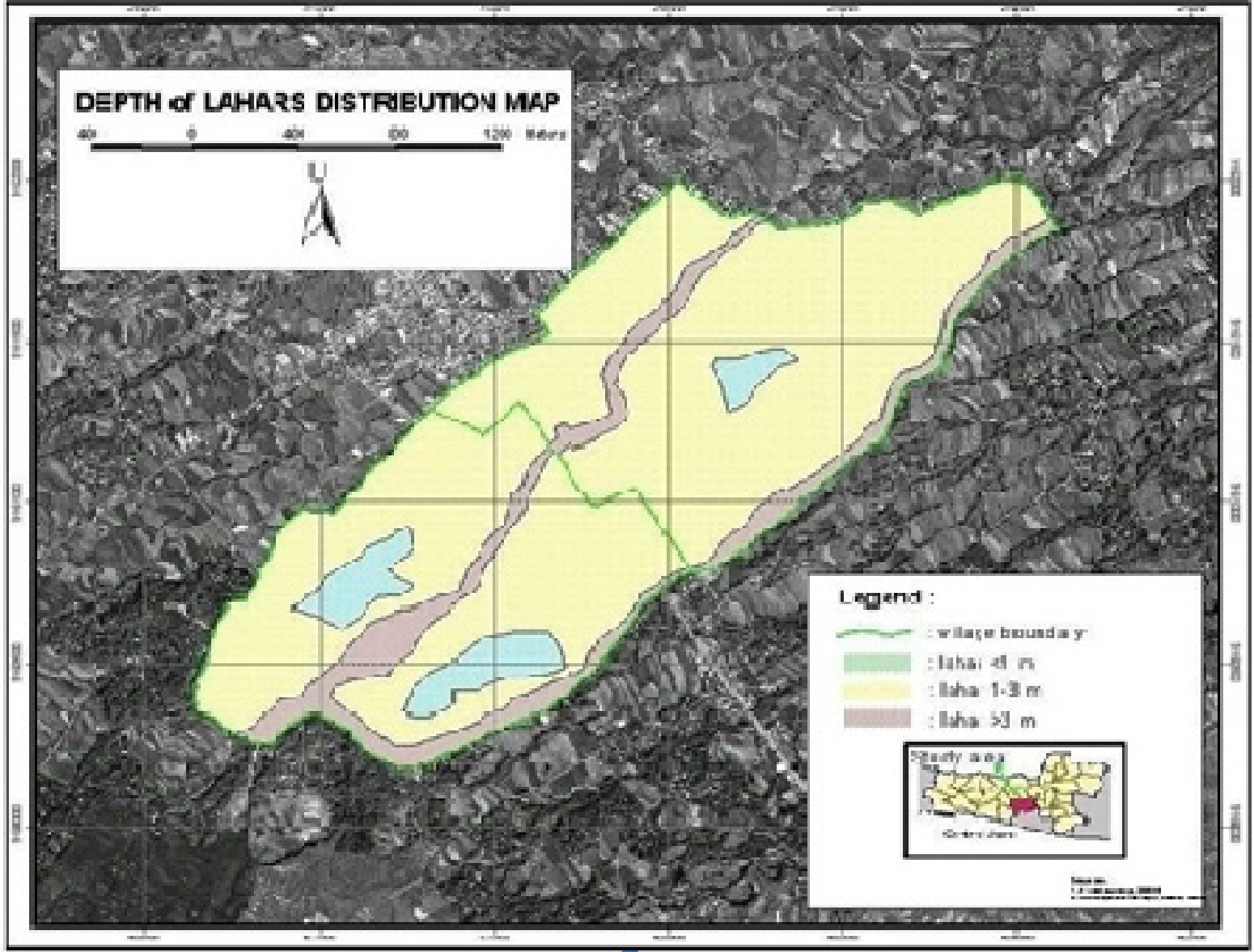

Figure 3. Lahar Flow Hazard Map in Muntilan Urban Area 


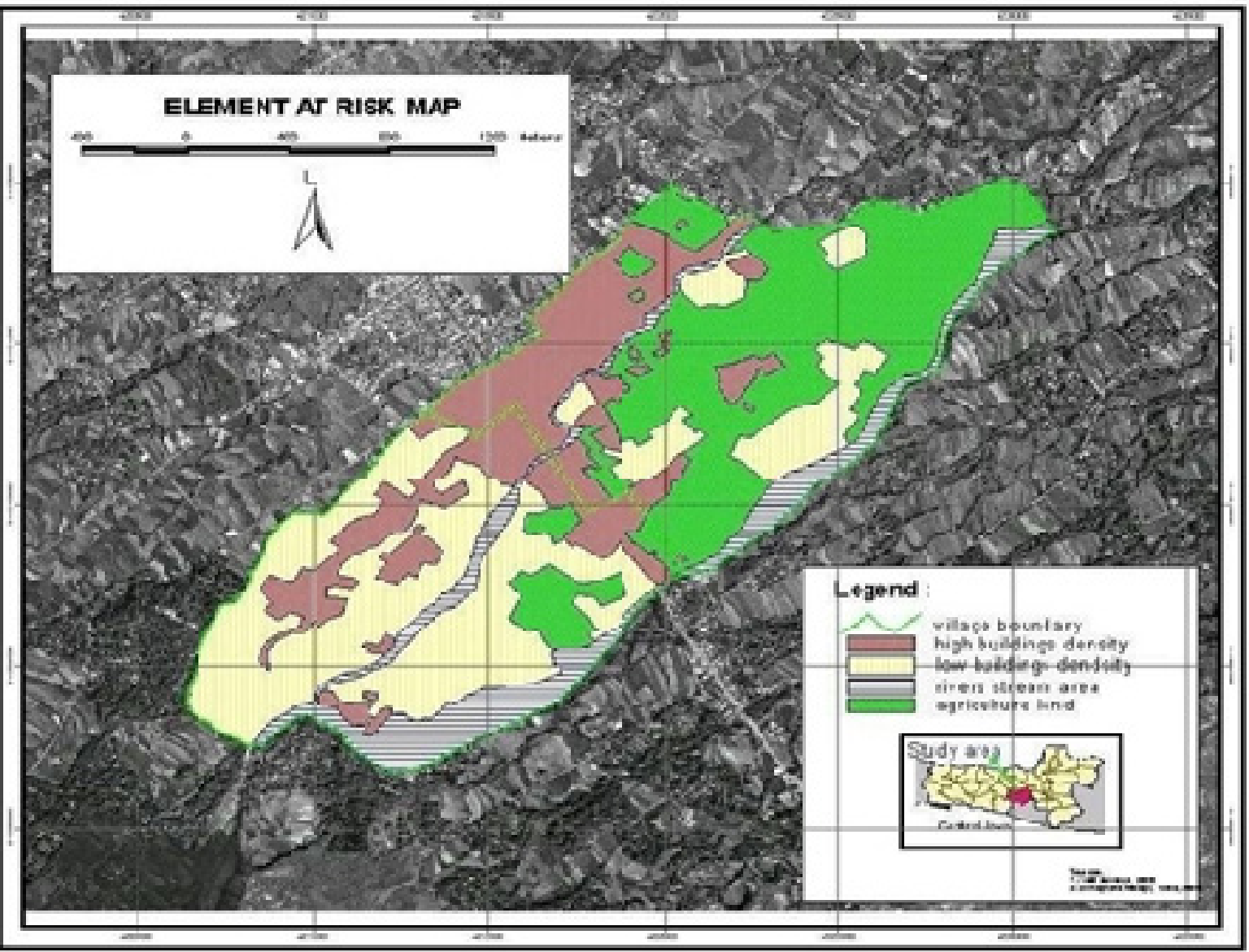

Figure 4. Lahar Flows Elements at Risk Map in Muntilan Urban Area

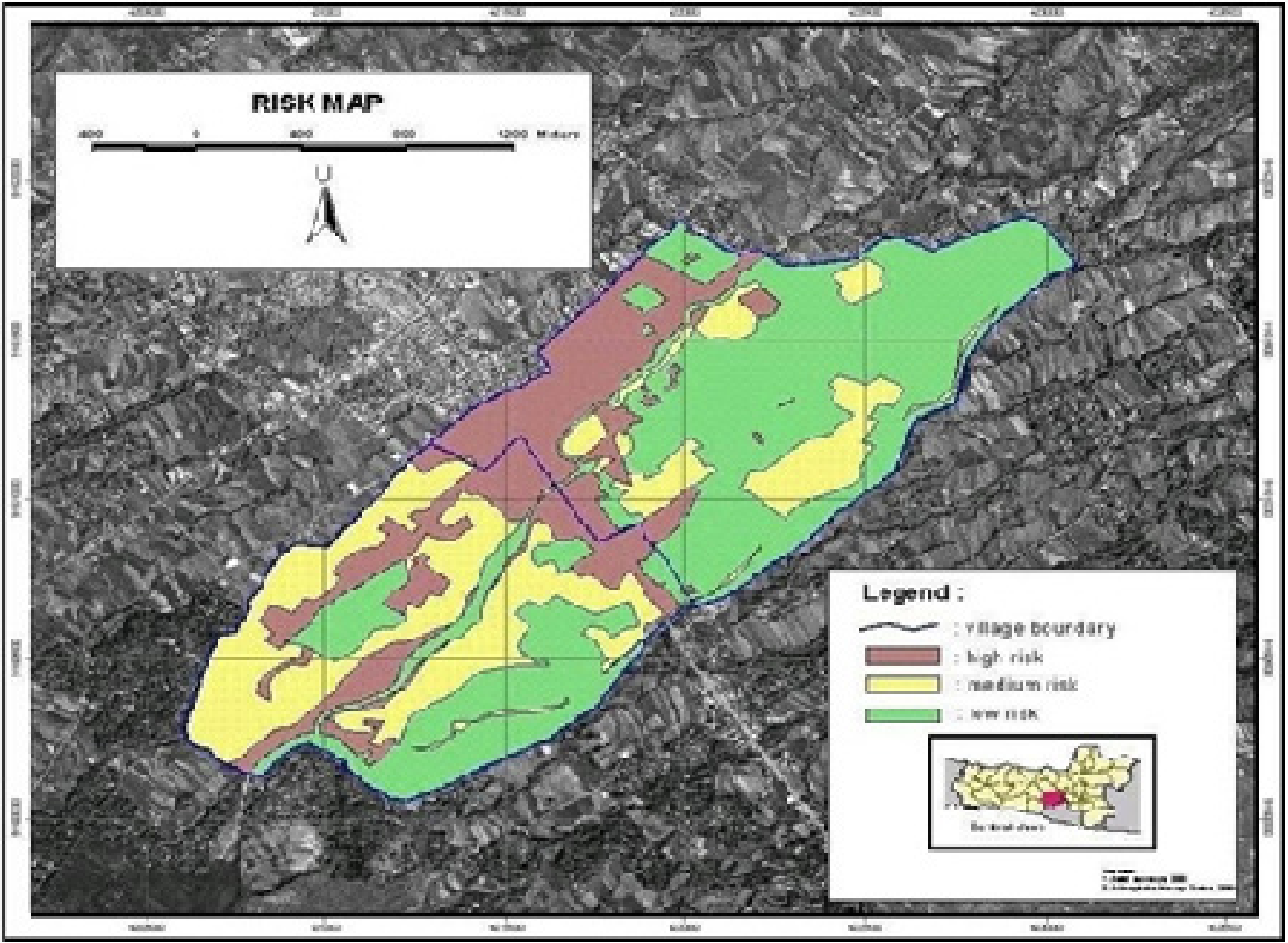

Figure 5. Lahar Flow Risk Map in Muntilan Urban Area 
Elements at risk map as presented in Figure 4. is constitute of classification of elements at risk in that area. The elements at risk tol classification for deciding of elements at risk integrate in order to optimize the risk map in future. The elements at risk in lahar flows hazard map is classify as presented in Table 2 .

In the Figure 5 presented of the risk map in urban area. By analysing of each elements at risk can devided into element value, and then by comparing each value of elements, it can be devided into three level of risk. Table 3 classification of elements at risk is influential with risk level as presented in Table. 4

Table 1. Classification of lahar depth

\begin{tabular}{lll}
\hline No & Depth of Lahar Material & Colour of Classification \\
\hline 1 & Lahar material $>3 \mathrm{~m}$ & Red \\
2 & Lahar material $1-3 \mathrm{~m}$ & Yellow \\
3 & Lahar material $<1 \mathrm{~m}$ & Green \\
\hline
\end{tabular}

Table 2. Elements at risk in Muntilan urban area

\begin{tabular}{lll}
\hline No & Element at risk & Colour of Classification \\
\hline 1 & high building density & Red \\
2 & low building density & Yellow \\
3 & river stream area & lines \\
4 & land/agriculture area & green \\
\hline
\end{tabular}

Table 3. Risk level in Muntilan urban area

\begin{tabular}{llll}
\hline No & Elements at risk & Colour & Remarks \\
\hline 1 & high building density & Red & High risk \\
2 & low building density & yellow & Medium risk \\
3 & river stream area, & green & Low risk \\
& land/agriculture area & & \\
\hline
\end{tabular}

This risk assessment is intended to provide information that will help communities to identify and prioritize mitigation activities that will reduce losses from the identified hazards.

The essential data required for risk assessment are the lahar flows hazard map with different depth of lahar flows buried in risk area, distribution of the elements at risk, and status of a land cover area. By integrating these data, a general procedure how to determine the analysis of the elements at risk caused by lahar flows hazard is presented in Figure 3.

Identification and inventory of element at risks can be conducted by digitizing the land use type directly from aerial photographs (Figure 4) scale $1: 12.500$. Theses element at risks can be classified based on the land utilisation presented in aerial photograph combined with the secondary data from Muntilan District. Three major of element at risk have been classified based on their types e.g. building, agriculture area, gardens and river stream. Result of calculation of element at risk can be presented in Table 4. In this case, the economic value of each element at risks can not be included in this analysis because the buildings in risk map can not be classified based on their function. Therefore we present now only the number of buildings, area of agriculture region and area of garden potentially threatened by lahar flows.

We classify three level of risks based on the number and density of building, with the assumption that the higher density of building cause the high level of risk. If certain areas have no building so the number of people potentially endangered by lahar flows is actually low. The high hazard level is characterized by the depth of the lahar flow is more than 3 meters $(46,583 \mathrm{Ha})$ which distributed along the channels. The secondary class is the medium class whose $1-3$ meters of depth. (459.34 $\mathrm{Ha}$ ). The lowest hazard level is considered by the lahar depth lower than 1 mater $(23.271 \mathrm{Ha})$. The criterion used to classify the risk level is the density of building with the assumption that the density of building represents the population of theses area. The highest risk can be found in the low hazard area because the building density is 17.19 unit/Ha. The building density of the medium level is $7.71 \mathrm{unit} / \mathrm{ha}$ and the lowest risk of theses area is characterised by the density value 1.78 units/ ha.

\section{Conclusion}

A part of volcanic deposit materials remain past activities 1998 still settle in Western-north of Merapi slopes area, as upper stream of Senowo, Lamat and Sat rivers. Be found lahars deposit materials in along Lamat river, that is lahar flows evident passing that river. Along as Lamat river be found small river channel capacity, especially in down stream of that river. The river channel capacity becomes small in down stream area because

Table 4. Calculation of element at risk in Muntilan Urban Area

\begin{tabular}{llllllll}
\hline No & Hazard level & Area (Ha) & Lahar depth & $\begin{array}{l}\text { Type of ele- } \\
\text { ment at risk }\end{array}$ & $\begin{array}{l}\text { Number } \\
\text { Of } \\
\text { Building }\end{array}$ & $\begin{array}{l}\text { Densities } \\
\text { of } \\
\text { building }\end{array}$ & Risk level \\
\hline 1 & Low & 23.271 & $<1$ meter & building & 400 & 17.18878 & high \\
2 & Medium & 304.684 & $1-3 \mathrm{~m}$ & building & 2352 & 7.719473 & medium \\
3 & High & 46.583 & $>3 \mathrm{~m}$ & building & 83 & 1.781766 & low \\
4 & Medium & 105.415 & $1-3 \mathrm{~m}$ & rice field & - & - & low \\
5 & Medium & 49.24 & $1-3 \mathrm{~m}$ & garden & - & - & low \\
\hline
\end{tabular}


type of river morphology (natural reason) and local societies construct small bride on the river (additional reason. According the analysing of river morphology in Muntilan urban area (down stream of Lamat river) that area constitute of lahar flows risk.

By using the risk map and elements at risk in Muntilan urban area can make risk assessment of lahar flows for Mitigation references. As the aim of this research was to come up with the risk map for the Muntilan urban area using JSAS numerical simulation and $G I S$ and $R S$, it is a good idea to predict the lahar flows occurrence which threatened Muntilan urban area and to provide the awareness to the local societies. Exceedingly the lahar flows occurrence in that area on more than 74 years ago, may the local societies was forgotten with the disaster and not aware. On the other hand the lahar flows occurrence is very much influenced by the topography and geomorphology. For example the river channel capacity of Lamat river located in the Muntilan urban area, On the Ketunggeng bridge (elevation + $438 \mathrm{~m}$ ) until the river confluence with Blongkeng river (elevation $+313 \mathrm{~m}$ ), the river wide is narrow (around $6.0 \mathrm{~m}-16.5 \mathrm{~m}$ ) and the river bank is low (only 2.50 $\mathrm{m}-9.0 \mathrm{~m}$ ). Local societies who live in Muntilan urban area constructed many bridges, were caused river channel capacity is decrease.

Muntilan urban area was located in do Stream of Lamat River is dangerous area from the lahar flow when the pyroclastic flow materals from the activity of Merapi volcano flowing to the western flank. According the JSAS Numerical Simulation for lahar flows in Lamat river the lahar flows threaten in Muntilan urban area will occur on 100 year return period. The software of JSAS would be implemented for numerical simulation for lahar flows movement. By using GIS dynamic modelling the digital orthophoto is able to create a risk assessment of lahar flows in Muntilan urban area.

The result of this thesis can predicts hazard and risk map of lahar flows in Muntilan urban area with the

\section{References}

Burrough, P.A., (1989), Matching spatial databases and quantitative models in land resource assessment. In: Soil Use and Management, 5(1989)1, pp. 3-8.

ITC Module. (2004), Risk Analisis Using RS/GIS. The Netherlands.

Itoh, H., Miyamoto K., Takahashi M., Takahama J., (2000), Hazard Estimation of the Possible Pyroclastic Flow Disaster Using Numerical Simulation Related to the 1994 Activity at Merapi Volcano. Journal of Volcanology and Geothermal Research.

van Westen, C.J. and Daag, A.S., (2005), Analysing the relation between rainfall characteristics and lahar activity at Mount Pinatubo, Philippines. Earth surface processes and landforms : the journal of the British geomorphological research group, 30(13): 1663-1674. hazard, risk levels each area and also can predicts the risk assessment of elements at risk area. The principle of Sabo facilities is controlling the sediment supplies in the river channel in order to keep the base of river channel stable. When the sediment supplies from the sediment yield is over from the capacity of sabo dam, that materials will still covered in down stream area. The sediment supplies are depending of total volcanic deposit and rainfall intense.

\section{Recommendation}

Comparing to historical data, the simulation of lahar flows results are not fit properly. Weaknesses of the simulation modeling are: (1) a good idea to once again verify on the field to check the lahar flows activity was threatened of Muntilan urban area. This is important because the hazard map and risk map of lahar flows by using JSAS numerical simulation as influenced with many parameters are static in nature and they may not take into consideration of the dramatic change of the causative agents, which are difficult to predict with high precision. For example rainfall, certain amount of rainfall triggers lahar flows. (2)lLocal government is better reminding to the inhabitants of Muntilan urban area for lahar flows risk. By using socialization program the government can use the result of this paper to inform to the local society about lahar flows hazard in risk area. If necessary, the result can make reference to implement disaster mitigation regulation for the local society, (3) the local government necessary actualize the spatial planning policy, which to prevent local society are constructing house in the disaster prone area, such as in the risk lahar flows area. And the government invite to the local society for together take care of the real river function, (4) the government and local society must participate to keep existence of lahar flows countermeasures facilities, such as sabo facilities, lahar flows forecasting equipment and Warning system equipment.

Yamashita, S., (2006), Hazard Map of Sediment Movements Based on Numerical Simulation and Its Utilization. Presentation For Sabo Group Course; Volcanology and Sediment-Related Disaster Management. JICA Training Course. 